\title{
Use of autologous fibrin glue in dermatologic surgery: application of skin graft and second intention healing
}

\author{
Discipline of Dermatology and Hematology, Department of Clinical Medicine, \\ Faculdade de Ciências Médicas, Universidade Estadual de Campinas (UNICAMP) - Campinas, Brazil
}

\begin{abstract}
Objective: To evaluate the efficiency of biological sealant, an autologous fibrin glue, in dermatological surgery. Design: Randomized clinical trial. Setting: The Dermatology Service of Hospital das Clínicas, Universidade de Campinas (UNICAMP), referral center. Patients: 14 patients with malign epithelial cutaneoos tumors participated in the evaluation, each having two tumors, generally facial and symmetrical, in order to perform a comparative evaluation on the same individual. Procedures: The glue was prepared beforehand with a sample of autologous blood. Surgical extirpation of the tumor was followed by grafts or second intention healing. Outcomes: The efficiency of the sealant was then evaluated in relation to hemostasis, adhesion, surgical time and evolution of the granulation tissue, clinically and histologically. Results: Immediate hemostasis and graft adhesion, with a significant reduction of surgical time, and in the open wounds there was immediate hemostasis and a clinical increase in granulation tissue, but with no histological differences among the groups on the $7^{\text {th }}$ day. Conclusion: It is an adjuvant resource in skin cancer surgery.
\end{abstract}

Uniterms: Fibrin glue. Wound healing. Skin cancer. Dermatologic surgery.

\section{INTRODUCTION}

$\mathrm{N}$ otwithstanding the continuing development of new surgical techniques, some problems such as blood coagulation and healing still remain.

Dermatologic surgery has increased rapidly but one of its main indications is still the extirpation of malign cutaneous tumors, especially basal cell and squamous cell carcinomas. In such surgery, cutaneous tumors are often extensive and cause great tissue loss, requiring the utilization of grafts or, possibly, second intention healing.

\author{
Address for correspondence: \\ Aparecida Machado de Moraes \\ Disciplina de Dermatologia \\ Universidade de Campinas - UNICAMP \\ Cidade Universitária "Zeferino Vaz" \\ Campinas/SP - Brasil - CEP 13083-970
}

Many dressings have been tried in order to help the healing of these wounds and, currently, attention is more directed towards those of a biological nature. ${ }^{1}$

The first experiments in the use of fibrinogen as a tissue adhesive were carried out in $1940 .{ }^{2}$ The concept of fibrin glue became realistic in the 1970's, with the advent of techniques for isolation and concentration of coagulation factors. In 1972, the success of fibrin glue in repairing a peripheral nerve was described. ${ }^{3}$ Since then, there have been many reports of successes and the use of fibrin glue has been extended into several areas of medicine. $^{4-8}$

Many surgeons have indicated fibrin glue as the ideal sealant material and because of its human origin it is not toxic towards tissue. Fibrin glue promotes firm adhesion in seconds or minutes; it is reabsorbed within a few days after application, contains tissue more rapidly and decreases the risks of hematomas and graft losses..$^{9-11}$

Fibrin glue is commercially available and is produced from homologous plasmas. However, contamination risks, 
potentially related to the hepatitis $\mathrm{C}$ virus and $\mathrm{HIV},{ }^{12}$ have discouraged its production in many countries.

There are also reports of the production of fibrin glue by extraction of fibrinogen from animal serum, although there is discussion about the possibility of hypersensitivity reactions from heterologous proteins. ${ }^{13}$

Autologous fibrin glue may be produced from one blood unit $(500 \mathrm{ml})$. Fibrinogen is obtained from blood via centrifugation and cryoprecipitation techniques and is converted into fibrin glue by adding thrombin during surgery. Fibrinogen may be stored in a freezer at $-20^{\circ} \mathrm{C}$ and can be used for two years.

As previously mentioned, most dermatologic surgery is performed for the treatment of malign cutaneous tumors. When flap or grafting reconstruction techniques are used, the visualization of the tumor is difficult if there is a relapse. Thus, second intention healing favors the follow-up of surgical therapy.

Moreover, reconstruction techniques may become impossible in individuals with extensive actinic injury, who are likely to be deficient in cutaneous donor areas. Among other factors which may favor second intention healing, the reduction of surgical time and reduced patient morbidity should be mentioned.

The use of fibrin glue in second intention healing is relevant, since fibrin acts in the initial phase, facilitating progression to subsequent phases.

The aim of this study was to evaluate the effectiveness of autologous fibrin glue used in dermatological surgery with skin grafts and second intention healing, studying the hemostasy, adesivity, granulation tissue and surgical time.

\section{METHODS}

This study evaluated the effectiveness of autologous fibrin glue used in dermatological surgery under the following conditions.

Fourteen white patients, male and female, coming from the Dermatology Outpatient Department, Hospital das Clínicas,Unicamp, ranging from 30 to 90 years old, were evaluated. Patients presented histologically diagnosed basal cell and squamous cell carcinomas, with development as far as the reticular dermis. The individuals selected needed to have two lesions, preferably on the face, with a diameter of 1.0 to $5.0 \mathrm{~cm}$.

Once the above criteria were defined, patients were submitted to exeresis around the injury, with a $4.0 \mathrm{~mm}$

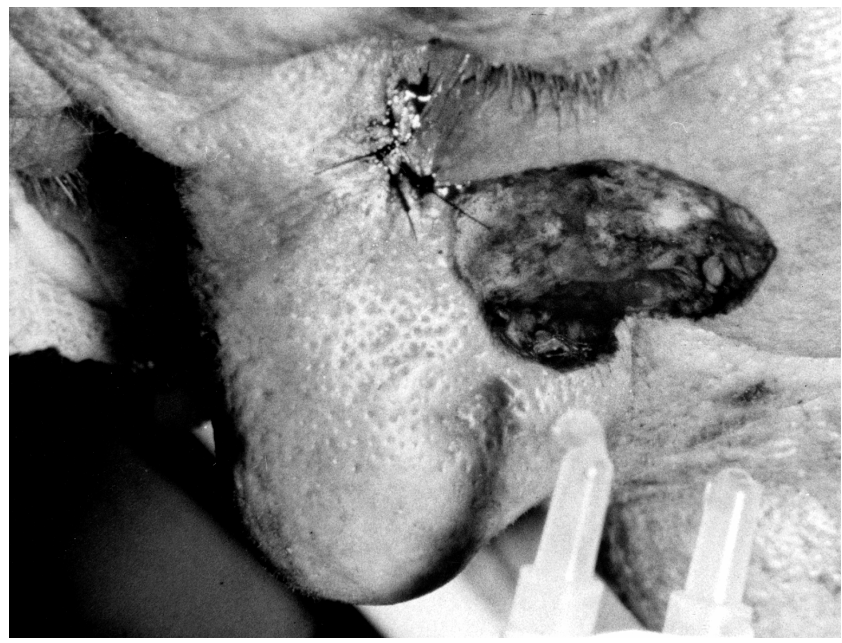

Figure 1 - Case 5: collocation of thrombin and fibrinogen, after the excision of cutaneous tumor (BCC).

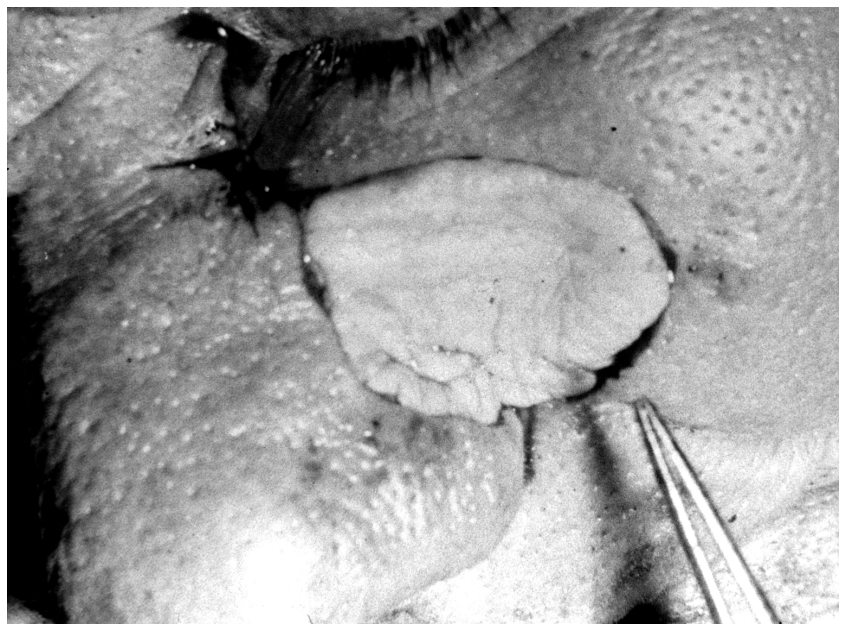

Figure 2 - Case 5: fast adhesion of the cutaneous graft.

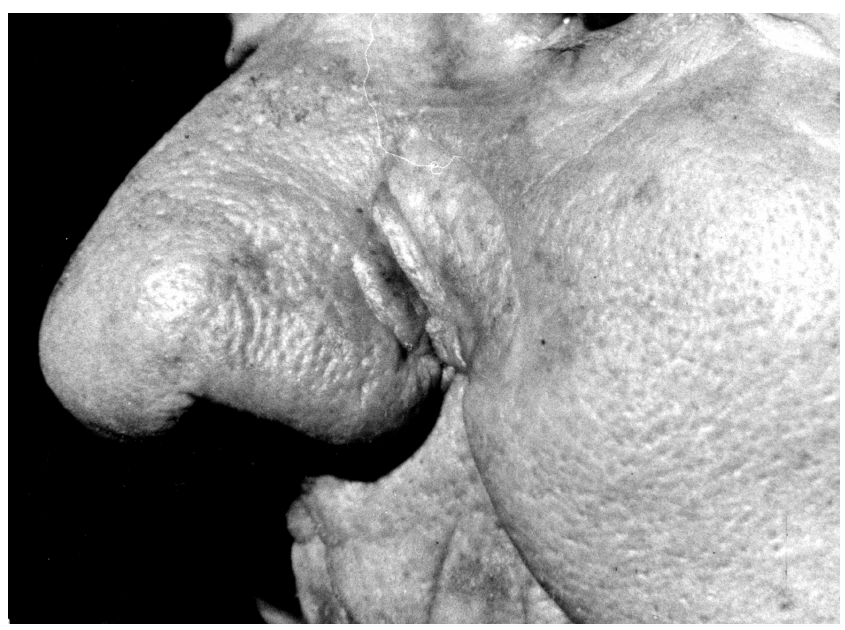

Figure 3 - Case 5: complete integration of the skin graft 3 months later. 
safety margin, under local anesthesia with $1 \%$ lidocaine without vasoconstrictor.

The patients were divided into two randomized groups by procedure: either reconstruction via graft or second intention healing. The treatment of the lesions was subdivided into four groups, according to the procedure:

A- Exeresis followed by graft, with use of fibrin glue;

B- Exeresis followed by graft, without use of fibrin glue;

C- Exeresis and second intention healing, with use of fibrin glue;

D- Exeresis and second intention healing, without use of fibrin glue.

Thus, procedures A and B were performed on the same patient, preferably in symmetrical lesions, and so were procedures $\mathrm{C}$ and $\mathrm{D}$.

In the lesions submitted to cutaneous grafts, the autologous fibrin glue was placed first, followed by grafting. After graft adhesion, a dressing with $1 \%$ garamycin cream was applied, followed by occlusion using gauze and micropore-type adhesive tape. In control injuries, grafting was placed in the usual manner with suture using a black 5.0 single-strand thread, followed by application of Brown's dressing. The same garamycin cream was also applied underneath the dressing.

In the lesions left for second intention healing, fibrin glue was placed directly onto the base of the surgery, followed by a dressing with $1 \%$ garamycin cream and occlusion using gauze and adhesive tape. In controls, garamycin cream was applied directly onto the base of the surgery. All lesions received occlusive bandaging with garamycin cream, changed daily for 7 days.

The tumours chosen for second intention healing were those poorly delimited, where there were relapses or sclerodermiform basal cell carcinomas.

All grafted injuries were evaluated on the 1st, 3rd, 7 th and 30th post-operative days. Brown's dressing was removed after 72 hours, and the suture after 7 days.

The lesions left for second intention healing were evaluated on the same days, although also applying fibrin glue to the lesions of group $\mathrm{C}$ on the 1st, 3rd and 7th days. Both groups had their occlusive bandaging changed daily.

A histological sample was taken from the lesions of groups $\mathrm{C}$ and $\mathrm{D}$ for evaluation of the progress of second intention healing on the 7th post-operative day. A tissue fragment was collected using a $4 \mathrm{~mm}$ punch on the base of the surgery, at a distance of $5 \mathrm{~mm}$ from the margin.

\section{Processing of autologous fibrin glue}

To produce autologous fibrin glue, only $50 \mathrm{ml}$ of blood was drawn from each patient. The blood was drawn using sodium citrate at $3.8 \%$, in a proportion of $9: 1$, centrifugated for 10 minutes at $3000 \mathrm{rpm}$ to separate the plasma.

\section{Purification of fibrinogen}

The purification of plasmatic fibrinogen was performed via the glycine precipitation technique. Under controlled temperature and concentration, glycine separates out only the plasmatic fibrinogen.

Anhydrous magnesium sulphate and barium sulphate, at a final concentration of $20 \mathrm{mM} / 1$ and $90 \mathrm{~g} / \mathrm{l}$, respectively, were added to $25 \mathrm{ml}$ of the plasma. After agitation for one hour, the supernatant was centrifugated and separated. This procedure was repeated once more. After measuring the supernatant plasma, glycine was slowly added to a final concentration of $2.2 \mathrm{M} / \mathrm{l}$. Again, the product was agitated for 30 minutes followed by centrifugation for 20 minutes.

The supernatant was discarded and the deposit was resuspended to the initial plasmatic volume, using 0.055 $\mathrm{M}$ sodium citrate, at $\mathrm{pH}$ 7.4. Then, glycine precipitation was carried out again.

Finally, the deposit was resuspended in PBS to a final concentration of $800 \mathrm{mg} / \mathrm{ml}$, aliquoted and frozen at $-20^{\circ} \mathrm{C}$.

\section{Use of fibrin glue}

After the ablation of the tumoral lesion, autologous fibrinogen and human thrombin were concomitantly applied, resulting in a viscous substance. This material was applied either via separate syringes or as a spray. Then, either cutaneous grafting was placed over this material or the wound was left for second intention healing. In this latter situation, the fibrin glue was reapplied on the 1st, 3rd and 7 th post-operative days.

\section{RESULTS}

In Table 1, tumour size, histological type, location and surgical type are described. All excised tumours were histopathologically examined and found to be free from neoplastic cells at the borders.

\section{Wounds with grafts}

In the lesions submitted to cutaneous grafting and covered with fibrin glue, hemostasis was instantaneous 
Table 1

Patients divided according to tumor site, histopathological classification and surgical type.

\begin{tabular}{cccccc}
\hline No. & Patient & Histology $^{*}$ & Diameter $^{\star *}$ & Site & Surgical type \\
\hline 1 & DPC & BCC & $2.0 \mathrm{~cm} / 2.0 \mathrm{~cm}$ & Face & Graft \\
2 & AS & BCC & $2.0 \mathrm{~cm} / 2.0 \mathrm{~cm}$ & Face & Graft \\
3 & GPM & BCC & $1.5 \mathrm{~cm} / 1.5 \mathrm{~cm}$ & Face & Graft \\
4 & WS & BCC & $1.5 \mathrm{~cm} / 1.0 \mathrm{~cm}$ & Face & Graft \\
5 & DB & BCC & $2.0 \mathrm{~cm} / 2.5 \mathrm{~cm}$ & Face & Graft \\
6 & WB & BCC & $2.5 \mathrm{~cm} / 2.0 \mathrm{~cm}$ & Face & Graft \\
7 & ACV & BCC & $2.5 \mathrm{~cm} / 2.0 \mathrm{~cm}$ & Face & Second intention \\
8 & LBP & BCC & $2.5 \mathrm{~cm} / 2.5 \mathrm{~cm}$ & Face & Second intention \\
9 & AF & SCC & $1.0 \mathrm{~cm} / 1.5 \mathrm{~cm}$ & Face $/$ sternum & Second intension \\
10 & JC & BCC and SCC & $2.0 \mathrm{~cm} / 2.0 \mathrm{~cm}$ & Face & Second intention \\
11 & CM & BCC and SCC & $3.0 \mathrm{~cm} / 3.0 \mathrm{~cm}$ & Face & Second intention \\
12 & II & SCC & $3.0 \mathrm{~cm} / 2.0 \mathrm{~cm}$ & Face & Second intention \\
13 & SN & BCC and SCC & $2.0 \mathrm{~cm} / 2.0 \mathrm{~cm}$ & Face & Second intention \\
14 & LLS & BCC & $4.0 \mathrm{~cm} / 3.5 \mathrm{~cm}$ & Face & Second intention \\
\hline
\end{tabular}

* Histopathological examination was performed before surgery and was defined as BCC (Basal Cell Carcinoma) or SCC (Squamous Cell Carcinoma).

** The diameter considered was the greatest axis of the surgical area obtained after excision of the tumorous part.

and the adhesion of the graft was also firm and immediate. These benefits noticeably reduced surgical time to around 3 minutes.

In the control injuries, where Brown's dressing was used, the surgical time was much longer, approximately 20 minutes.

The 7 th and 30th day evaluations showed no differences between the groups.

\section{Wounds with second intention healing}

Lesions left for second intention healing using fibrin glue showed immediate hemostasis and, clinically, more exuberant granulation tissue in the immediate intraoperative and post-operative periods. But from the 7th post-operative day, the evolution of the injuries was similar.

Histological examination of the bases of the wounds left for second intention healing was performed via biopsy taken at $5 \mathrm{~mm}$ from the healing margin of the surgical wound on the 7th day, in 4 wounds left for second intention healing (two with and two without fibrin glue). Macroscopically, the fragments presented tissue in the granulation phase. However, there was no histological difference between the fragments with and without fibrin glue when evaluated with hematoxylineosin staining.

\section{DISCUSSION}

The use of fibrin glue has been described in many situations, such as repair of the peripheral nerves and other visceras, fistula occlusion, surgery of cerebral tumors, skin grafting and application in burned patients. ${ }^{4,5,7,9,11,14-18,21,22}$ The continuing evolution in the preparation and use of fibrin glue is emphasized in the literature.

Reconstruction in dermatological surgery treating malignant cutaneous tumors may be made difficult due to extensive cutaneous involvement or location in anatomical areas with difficult access. Great tissue loss requires the use of grafting or, possibly, second intention healing. The latter is indicated for poorly delimited relapsing tumors which require a long follow-up without reconstruction, so as not to make visualization of new tumoral growth difficult.

In our study, the use of fibrin glue in these two situations, the application of grafting and second intention healing, was examined as three topics:

\section{Application of cutaneous grafting}

The use of fibrin glue in the intra-operative period greatly facilitated surgery because hemostasis was immediate. The adhesion of the grafts was firm and suture was not necessary, thus reducing the surgical time when compared to control 
injuries. These findings corroborate those of Dahlstrom et al; ${ }^{5}$ Gibble and Ness, ${ }^{1}$ Lilius $;{ }^{8}$ and Tildrick and Warner. ${ }^{21}$

Efficient hemostasis is reported in various studies, and as the principal advantage of fibrin glue in surgery on organs with nonsuturable hemorrhage, such as liver, spleen and retroperitoneal surfaces. ${ }^{12,18}$ The firm adhesion that facilitates the joining of tissues is also reported in various studies involving surgery on internal organs..$^{714-16,18-20}$

In a preliminary study on 12 patients, Bizzachi et al. ${ }^{11}$ used fibrin glue for the application of cutaneous grafting after exeresis of facial tumors. Our results corroborate that report, with a reduction of surgical time and good esthetic results.

Due to the rapid and efficient hemostasis, it was observed during clinical evolution that there was no development of hematomas and if they showed up at all, they were small and did not develop a corresponding necrosis. Up until now, there has not been any epitheliolisis in the grafts with fibrin glue.

Most patients submitted to dermatological surgery are carriers of tumoral actinic lesions resulting from exposure to solar radiation. The availability of fibrin glue is yet another means for performing reconstruction in patients who frequently have to undergo several surgical operations.

\section{Second intention healing}

Fibrin glue has also been shown to be useful in the intra-operative period in lesions left for second intention healing, due to the rapid hemostasis.

In the evolution of healing, development of more evident granulation tissue occurred in lesions with fibrin glue. Since fibrin glue was applied on the 1st, 3rd, and 7th days in this group, the supposition was that the cell migration stimulus triggered in the repair was higher in these cases. The application of glue was not recommended after this time, as it is known that the fundamental role of fibrin is played in the initial phase of the healing period. Moreover, the maintenance of an aqueous medium in the wound is a determining factor in the evolution of healing. ${ }^{2,6}$

Brown et al reported a reduction in wound retraction in cutaneous grafts applied with fibrin glue. ${ }^{13}$ In this study, the reduction in retraction of grafted wounds was attributed to the graft itself, because the evolution of healing was similar to that of the control group.

In wounds left for second intention healing, glue did not interfere with the natural retraction of the wound. On the contrary, in the initial phase of healing, there was a real natural retraction, more rapid than in the cases without fibrin glue.

Histopathological examination of granulation tissue from open wounds on the 7th day, with and without fibrin glue, did not show any evolutive differences regarding healing and inflammatory cellular infiltration.
In another study performed experimentally on animal wounds using commercially produced heterologous glue, the inflammatory layer showed greater cellular content and fibroblasts had higher replication activity on the 5th day. ${ }^{3}$ The divergence of these findings is probably due to the small size of the fragments collected for our histopathological examinations, which was not the case in Galleti's study, ${ }^{3}$ in which the wounds were studied histologically after their complete ablation. The histology of these samples permitted complete evaluation of the center and depth of the wounds; this was not seen in small individual fragments.

The proliferation of keratinocytes in a matrix containing substrate with fibrin seems to be favored, as shown in the studies of Ronfard et al. These authors used fibrin glue in the culture of keratinocytes for the treatment of burned patients. Thus, the use of fibrin glue may favor the epithelization of open wounds. ${ }^{17,21}$

In this study, there was no secondary infection in any of the cases although all the wounds received garamycin cream. It was noticeable that in the cases where fibrin glue was used, the antibiotic cream remained completely isolated, without becoming mixed up with the glue. This protective effect of fibrin glue against secondary infection was described by Jabs et al. ${ }^{10}$

\section{Preparation of fibrin glue}

One of the restrictions on the use of homologous fibrin glue is the possibility of contamination by virus, including the hepatitis $\mathrm{C}$ virus and HIV. The use of autologous fibrin glue excludes the risk of contamination, as long as the patient's own blood is used. Blood sampling for the elaboration of the autologous product was a procedure completely accepted by all patients.

In most of the studies reported, the preparation of autologous fibrin glue is made from a $500 \mathrm{ml}$ blood volume. This is a limiting factor for aged patients. The technique of fibrinogen isolation we used permitted the preparation of a good quality fibrin glue in adequate quantities, drawing only $50 \mathrm{ml}$ of blood from each patient.

A limiting factor for the use of fibrin glue is its cost, because the products commercially available are very expensive. Thus, another advantage of autologous fibrin glue is its low cost, although the patient has to go to hospital for blood sampling. ${ }^{25}$

In summary, these results favor the use of fibrin glue in surgery on dermatological tumors, either using grafts or second intention healing, as it facilitates the intraoperative period, reducing surgical time and favoring clinical evolution and the resultant healing. The storing of fibrin facilitates multiple surgical operations in patients with several cutaneous tumoral lesions. 


\section{REFERENCES}

1. Gibble JW, Ness PM. Fibrin glue: the perfect operative sealant? Transfusion 1990;30:741-7.

2. Dyson $\mathrm{M}$ et al. Comparison of the effects of moist and dry conditions on dermal repair. J Invest Dermatol 1988;91:434-9.

3. Galletti $G$ et al. La cicatrizzazione delle ferite: effecto protettivo della colla di fibrina? Minerva Chirurgica 1985;40:377-80.

4. Chakravorty RC, Sosnowiski KM. Autologous fibrin glue in full-thickness skin grafting. Ann Plast Surg 1989; 23:488-91.

5. Dahlstrom KK, Weis-Fogh US, Medgyesi S, Rostgaard J, Sorensen $\mathrm{H}$. The use of autologous fibrin adhesive in skin transplantation. Plast Reconstr Surg 1992;89:968-72; discussion 973-6.

6. Eaglestein WH. Experiences with biosynthetic dressings. J Am Ac Dermatol 1985;12:434-40.

7. Harting $\mathrm{F}$ et al. Glue fixation of split-skin graft to the bony orbit following exenteration. Plast Reconst Surg 1985;76:633-5

8. Lilius P. Fibrin adhesive: its use in sealed skin grafting. Scand J Plast Reconstr Hand Surg 1987;21:245-8.

9. Kram $\mathrm{HB}$ et al. Spraying of aerosolized fibrin glue in the treatment of nonsuturable hemorrhage. Am Surg 1991;57:381-4

10. Jabs AD et al. The effect of fibrin glue on skin grafts in infected sites. Plast Reconstr Surg 1992;89:268-71.

11. Bizzachi JMA et al. Utilisation de la colle de fibrine autologue en reconstruction faciale par greffes de peau totale. Ann Chir Plast Esthét 1994;39:125-7.
12. Byrne DJ et al. Effect of fibrin glues on the mechanical properties of healing wounds. Br J Surg 1991;78:841-3.

13. Brown, DM et al. Decrease wound contraction with fibrin glue-treated skin grafts. Arch Surg 1992:127:404-6

14. Kram HB et al. Use fibrin glue in hepatic trauma. N Trauma 1988;28:1195-2015.

15. Kram HB et al. Tracheal repair with fibrin glue. J Thorac Cardiovasc Surg 1985;90:771.

16. Matras $\mathrm{H}$ et al. Suture-free interfascicular nerve transplantation in animal experiments. Wien Med Wochenschr 1972;122:517-23.

17. Ronfard V et al. Use of human keratinocytes cultured on fibrin glue in the treatment of burn wounds. Burns 1991;17:181-4.

18. Ormann W, Hopf G. Spontaneous splenic rupture in infectious mononucleosis - Organ preserving operation by means of fibrin tissue adhesive. Langenbecks Arch Chir 1988;373:240-2.

19. Matras $H$. The use of fibrin sealant in oral and maxillofacial surgery. J Oral Maxillofac Surg 1982;40:617-22.

20. Wolner E. Fibrin gluing in cardiovascular surgery. Thorac Cardiovas Surg 1982;30:236-7.

21. Saltz et al. Application of autologous fibrin glue in burn wounds. J Burn Care Rehabil 1989;10:504-7.

22. Siedentop $\mathrm{KH}$ et al. Autologous fibrin tissue adhesive. Laryngoscope 1985;95:1074-6.

23. Stuart JD, Morgan RF, Keney JG. Single-donor fibrin glue for hand burns. Ann Plast Surg 1990;24:524-7.

24. Tildrik RT, Warner E. Fibrin fixation of skin transplants. Surgery 1984;15:90.

25. Dresdale A et al. Preparation of fibrin glue from singledonor fresh-frozen plasma. Surgery 1985;97:750-5.

\section{RESUMO}

Objetivo: Avaliar a eficácia de um selante biológico, a cola de fibrina autóloga, na cirurgia dermatológica. Tipo de estudo: Estudo prospectivo, randomizado. Participantes: 14 doentes com dois tumores cutâneos epiteliais malignos, principalmente faciais e simétricos, para avaliação comparativa no mesmo indivíduo. Local: Serviço de Dermatologia do Hospital de Clínicas da UNICAMP. Procedimentos: A cola foi preparada, previamente, com amostra de $50 \mathrm{ml}$ de sangue autólogo. Após a exérese do tumor, seguiu-se a colocação de enxertos ou cicatrização por segunda intensão. Variáveis: Hemostasia, adesão, tempo cirúrgico e evolução do tecido de granulação, clínica e histologicamente. Resultados: Os resultados com a cola mostraram hemostasia e adesão imediata dos enxertos, com redução significativa do tempo cirúrgico e nas feridas abertas houve hemostasia imediata e maior tecido de granulação clinicamente mas sem diferenças histológicas, no $7^{\circ}$ dia, entre os grupos. Conclusão: Concluiu-se que é recurso adjuvante na cirurgia do câncer de pele. 